\title{
Transition of a Western dream into an evidence of Guilt: \\ 2016 TAIPEI The case of Mekap shoes in Turkey
}

\author{
Emrah Ozturan / Istanbul Technical University / Istanbul / Turkey
}

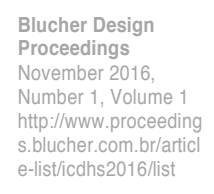

\begin{abstract}
This paper aims to document the case of Mekap-shoes in Turkey upon their social, political and economic testimonies, with a focus on artefacts-politics relationship in the core. Within a polarized society in terms of identity issues, and a partially closed economy with statecontrolled import barriers, Mekap became the first company producing sneakers in Turkey in 1970 's. With its stylish, affordable and durable models, suddenly it had gained an important market-share and popularity especially among youngsters and middle classes. But by mid1980 's, the destiny of the shoes had been changed unexpectedly and unintentionally, in parallel to the economic and political shifts in the country; as Mekaps begun to be associated respectively with working class, left ideology and an armed movement, by the help of various actors, especially politicians and mass-media. First appeared in the market by rendering a western dream to middle classes, by time Mekaps turned into sacred terrorist shoes or resistance objects depending on the standpoint.
\end{abstract}

\section{Keywords}

Material culture, design history, design as politics, resistance objects, Mekap-shoes

\section{Introduction}

This paper aims to present the recent history of Mekap-shoes in Turkey, as an unstudied but prominent case for objects' appropriation by different communities and user groups; and their intermediating roles in social contexts. In contrast to many politicised objects where historical or ideological references were built/invented deliberatively beforehand; this case presents an association gained by pure functional and use-related reasons, and without the intention or involvement of neither its manufacturer nor imagined users. This paper, which is placed at the intersection of design history and material culture studies, may be divided into four sections. First, a conceptual framework will be presented, which will be followed by a two-phased research on the history of Mekaps, and a final chapter of conclusion.

\section{Conceptual framework}

Artefacts are to present some hidden but valuable and also reliable knowledge derived from their social lives, their production-consumption-mediation cycles, the environments and contexts they appeared, and the actors they had interacted with. According to Lees-Maffei (2009), the world is mediated through objects, whereas studying mediation means studying the phenomena that exist between production and consumption, that is to inscribe and illuminate meanings for objects (Lees-Maffei, 2009). In this sense, some everyday objects that used to be perceived as fameless, vain or ordinary, had begun to gain scholarly interest by their potential of revealing hidden knowledge upon their social, economic, cultural and political testimonies.

Entities of our built environment are situated under grift web of social and cultural relations. Beyond their primary and physical functions, they also have immaterial, multi-layered meaningful cores embedded in them. The objects with recognised political/ideological meanings, which are central to this study, may mobilise or prioritise specific social or ideological groups, movements, classes or sub-cultures that are forgathered for specific purposes. These groups tend to embrace the object, symbolise, politicise, transform or manipulate it by imputing novel meanings, usually with historical references, invented traditions or myths, and rarely with functional or practical 
reasons. These appropriations can be consciously planned and compromised, or incidental and spontaneous. According to Fallan (2010), these appropriations generate a rich medium to study objects in order to examine how customers/users re-contextualise commodities by integrating them in their own worlds.

The case this paper deals with, the story of a footwear, suits the category of dress and accessories, which used to be the most visible area of such associations by their supreme visibilities and physical relationship with the body. According to Himam (2007), the stories of dress in specific time periods form important mediums to see that country's historical evolution and individuals' transition in a historical context (Himam, 2007). In addition to well-studied official, imperial or military dress codes, many social groups, tribes, ideological or paramilitary movements had also been recognised by their specific dresses or even designated themselves upon their symbolic and unique clothing, such as Camicie nere (Blackshirts), Sturmabteilung (Brownshirts) or Ku Klux Klan. Edensor (2002) agrees that specific clothing used to represent specific ideological or national belongings and senses. For instance Zhongshan/Mao uniforms represent Chinese solidarity, Nehru jackets represent anti-colonial Hindu movement, and American jeans represent democracy, comfort and freedom (Edensor, 2002). Similar examples are also visible in Turkish history, especially on headgears, whereas the histories of fez, turban, fedora, casquette, kalpak, kufiya or headscarf reveal some hidden knowledge through their historical testimonies, and act as historical documents and agents to enlighten social and cultural histories (Ozturan, 2015). Such cases indicate that, individuals tend to use these visible accessories to reveal and publicise their social, cultural, ethnic or political identities and also belongings to specific groups. Apart from the individuals, these common uses of specific objects also function for the community itself; as Simmel (1971) states that fashion is a product of class division, and it both functions by holding a specific group together and also making that group closed to others.

\section{Mekap shoes: A historical case study}

The story of Mekap-shoes is to present a prominent case study on the semantic transformation of a commodity, upon social and political appropriations and testimonies. The case both presents frameworks on the brand's intended interaction with its targeted users, and an unintended interaction between the commodity and the user. In that sense, it largely overlaps Gottdiener's (1995) model for mass cultural semiosis. His two-staged model argues both the relationship between the producer and the user, and also between the object and the user. According to his model, in the first stage of semiosis the exchange value of production turns into the use value of consumption, which forms a relationship between the producer and the user by the discourse of advertising. And in the second stage, the relationship between the producer and the user turns into the relationship between the user and the object, as consumers make certain objects act as their cultural codes within society to differentiate/identify themselves, either as individuals or groups (Gottdiener, 1995).

\section{ChasIng a Western dream: Mekap at 1970's and 1980's}

This section covers a brief historical background on Mekap's early years, with a parallel reading on the economic, social and political background of the mentioned years. The relationship between the producer and the user to be stated here fits the first stage of Gottdiener's (1995) semiosis model. And another point to be noted here is, although Mekap produced various models throughout time, all the references in this paper belong to its one of the earliest and by far the most famous yellow/brown sneaker model.

Founded in 1972, and today still acting with the brand name Mekap, the company holds a production capacity of two-and-a-half million pairs of shoes per year, in its factory in Trabzon. Having an almost closed economy with state-controlled import barriers in 1970's, Mekap became the first Turkish brand producing sneakers with polyurethane injected soles, and used to be a well-known actor in the local market since then. In 1996, the company changed its focus on work-safety shoes with commercial concerns, as a benefit derived from the brand's established perception regarding reliability, durability and safety (Url-1).

According to Karlıklı (2003), rarely seen sneakers in Turkish market at 1970's were some Adidas, Converse or Onitsuka Tiger products that had individually supplied from foreign countries, and some that are secured from American soldiers based in the country. Yet, such sneakers were quite popular among especially youngsters. Observing this rising passion and demand for sneakers among young people, entrepreneur Hikmet Kurşunoğlu transferred a new technology for the polyurethane injection, and Mekap brand had born with its first produced yellow and blue shoes (Karlıklı, 2003). In an interview in 2004, company's second-generation representative and acting-chairman Kenan Kurşunoğlu declares that, Mekap had its commercially best years between 1977 and 1980 , whereas daily production was around six-eight thousand pairs. In the same interview, he also states that in its 


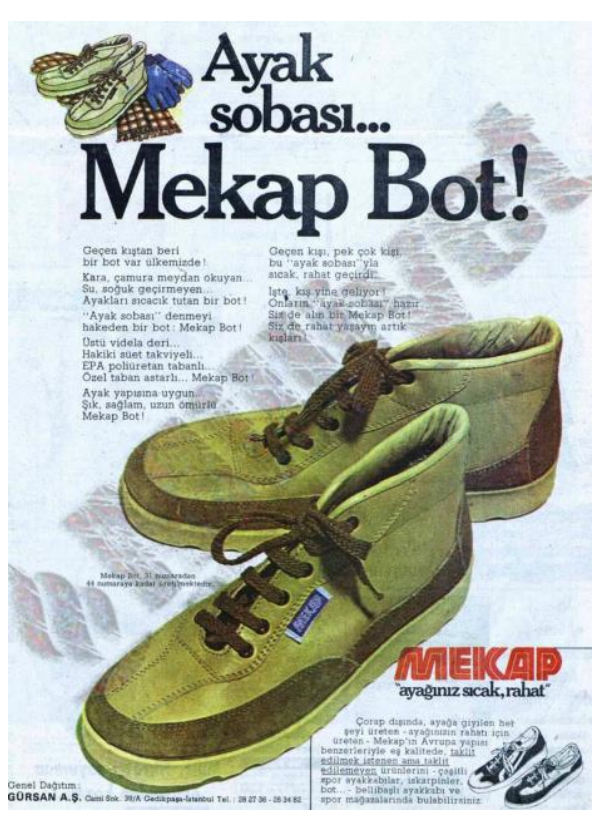

Fig. 1: "Foot Stove Mekap Boot" advertisement (Milliyet Gazetesi, 1981, October 21) first six months there were not enough interest in market, but later the company started an advertising campaign, and suddenly a massive interest on the shoes appeared and Mekaps became popular urbane and colleger shoes in a short period of time (Şen and Gemici, 2004, February 26). By the help of the closed economical setup resulting lack of competition, and the durable, stylish and affordable models they produce, suddenly Mekaps gained a significant popularity and market share, and regardless of the purchasing power or the social class, many people had been fond of these new sneakers. Karlıklı (2003) defines this status as the creation of a classless and coherent society, especially among young people. With the prominence of this sector, in the following years Mekap started to have competitors, and when Esem brand had appeared in the market with a more similar look to foreign models, soon Esems started to address upper-middle classes, while Mekapshoes retained its hegemony for low-income segments. And mid-80's witnessed an economical shift in Turkey, with the opening of customs stations and national economy's articulation to the global and liberal market. This change resulted the import of celebrated foreign brands that are to target mainly upper classes. And finally at the end of 80's, more affordable models had started to be imported from Far East, which made a final trigger to end the monotype sneakers era (Karlikli, 2003).

In order to understand the brand's self-promotion and self-positioning, and on the other hand the mediation between the producer and the consumer, having a look at some examples of brand's advertisements would be useful. When the digital archives of newspapers are reviewed, it is visible that the brand used printed media for advertising especially at late-70's and early-80's. These advertisements usually target the end user and rarely retailers. Summing up the advertising strategy of the brand, it could be claimed that the concepts of comfort, durability, strength, accessibility and health appears as key themes. Some references to the use of high standards in materials and production technology, and the sneakers' harmony with Western lifestyle and dress are also visible. For instance, an advertisement from 1981 was to emphasize durable, healthy and functional Mekap (Figure 1).

\section{Mekap as an ideological commodity: From 1980's to today}

The former section covering the first stage of Gottdiener's (1995) mass cultural semiosis model, which focuses on the relationship between the producer and the consumer may sound decent and ordinary, as a commercial history of a brand. But when focusing on the second stage of Gottdiener's (1995) model, to deal with the user-object relationship, an unexpected and unpredicted case appears; as the object, the Mekap-shoe starts to act as an independent social agent.

During 70's and 80's, within the lively ideological polarization driven by the left-right trajectories, expectedly Mekaps' association with lower-income groups had been carried to ideological scene, whereas Mekaps started to be perceived as workers shoes or leftist shoes. That resulted Mekaps becoming a powerful symbol and identity indicator among leftist and revolutionist groups, just as some other clothing such as green parka. In parallel, starting from mid-80's, but mainly in early-90's, a stronger and more function-based association was about to be occurred. Apart from Mekap's associations related to class and ideology, newly-formed militant left-wing movement PKK (Kurdistan Workers' Party) appropriated Mekaps in a purely functional manner, with their economically affordable, logistically reachable and physically durable features. PKK is an armed guerrilla movement, listed as a terrorist one by several states and organisations, and self-identifying its struggle on Kurds' cultural and political rights and self-determination in Turkey. Following its initial visibility in urban areas, by mid-80's they had adopted a Maoist approach and guerrilla methods, and started to act mainly in the mountainside of the South-eastern Turkey and Northern Iraq. Expectedly, this arduous geography and lifestyle gave rise to new physical needs for PKK militants whereas the self-declared characteristics of Mekaps, "comfortable, durable, healthy" was totally fulfilling them. When the ease in their accessibility and affordability had also added to these features, in a short period of time they started to use Mekaps in great numbers (Figure 2). This unpredicted appropriation could be claimed to be the result of brand's self-promotion and positioning in the market, the product's functional properties, widespread sales channels, and its already established leftist/revolutionary connotations. For instance, journalist Hasan Cemal narrates a 


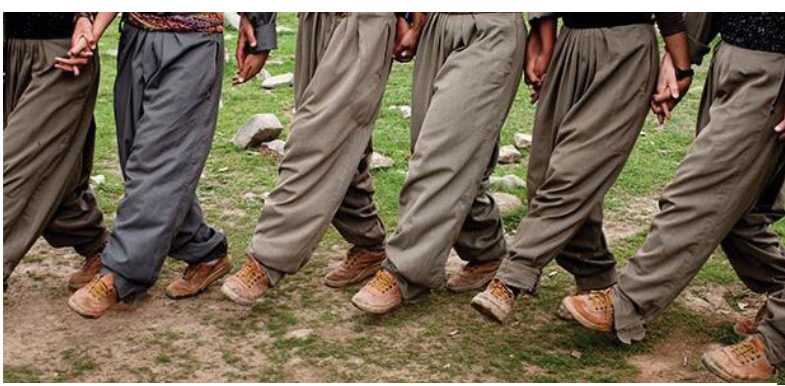

Fig. 2: A scene from a video clip that is banned by Turkey Radio and Television Supreme Council in early 2016 (Url-2) memory on Mekaps, from his interview with a PKK leader in 2013. On their way through mountainside and after mentioning that mountain-hiking is also included guerrilla training, his interviewee looks over his newly-purchased rubber shoes and tells they may slip on wet rocks or grass, and declares that "the best is our guerrillas' Mekaps, they do not slip" (Cemal, 2016).

On contrary to the similar cases seen in subcultures, this long lasting and still lively association had not been publicised by PKK militants or sympathisers. Instead they had probably just functioned physically, as durable and

affordable shoes in guerrilla life, whereas no proof or clue had been found in these years' press regarding the movement's self-designation on Mekaps as identity indicators. Yet, it was the state, the political figures and the mass media that publicised and popularised this appropriation. First, it was Turgut Özal (Turkish prime-minister 1983-1989, president 1989-1993) who defined PKK militants as "a handful of youngsters hiking in mountains with their Mekaps". As this association strengthens and popularises, the state and law enforcers perceived the shoes as an artefact out of favour; people using or selling Mekaps especially in South-eastern Turkey were suffered oppression, wearing Mekap is regarded as an evidence of terror affiliation, and even according to some personal narratives their sales had been banned for a while in 90's (Url-3, Url-4). This association between Mekaps and PKK militants, and its usage as a metaphor had been increased by years, especially during the times that the political debates, peace talks or military actions were livelier. For instance, recently, after 2013 when the Turkish state and the PKK began the peace negotiations explicitly, Mekaps again appeared on press metaphorically, referring the PKK militants. Within this discourse Mekap in a way clarified from its functionality and physicality, and just handled as something abstract, as a metaphor, although it had continued to be used physically in mountainsides among guerrillas and in urban life among sympathizers. A few cases among many could be illustrated whereas at 2002, when the state of emergency ended at the region, one could read "wearing Mekaps are free in East" on the headline of a newspaper (Url-3); at 2009, Prime Minister Recep Tayyip Erdoğan was uttering his discomfort on the Mekaps of the former guerrillas returning legally to Turkey (Url-5); at 2010, on a legal prosecution, a suspect's demand of Mekap shoes in a eavesdropped phone call had been mentioned in accusation as "suspect's demand for the specific brand of shoe that the terrorist organization members use" (Url-6); at 2013, Selahattin Demirtaş, co-leader of the pro-Kurdish political party $\mathrm{BDP}$, was describing walking, the probable scenario of guerrillas' leave of the country, metaphorically as Mekap method (Url-7); and in a demonstration aiming solidarity with Kurdish fighters that are in war with self-styled Islamic State in Kobanî, it was written "the ones with yellow Mekaps will defeat ISIL" in a poster (Url-8).

On the other hand and in the commercial scene, the company had commercially suffered from this association for decades, and several times declared their support for the state, condemned the terrorism and the PKK movement and repeatedly stated they have no influence on guerrillas' access to the shoes. At 2013, while complaining about this association, they even declared that if terror will end as they stop manufacturing Mekaps, they would resolutely do that. Besides they claimed their support to recent peace talks, in a sense that a probable peace could result Mekap-PKK association just remain as nostalgia (Oğhan, 2013, May 5).

And lastly, to render the recent situation on the issue, it can be stated that the company's focus had been shifted to a new area, work-safety shoes; it still discomforts the general anti-PKK public who perceive it as a separatist/terrorist symbol; most PKK militants still use it in a physically; for civilian PKK sympathisers, it derived into an identity symbol and a blessed commodity; and the media still use it as a metaphor to point out guerrillas.

\section{Conclusion}

This paper aimed to document the story of Mekap-shoes, which had not found scholarly interest yet in spite of its wide publicity. It could be stated that most of the objects emblematised by ideologies or social movements in history are products of conscious and intended appropriations, usually far from or with a little reference to the object itself, to its physical functions or its use. On contrary, what makes the case of Mekaps prominent is also its appropriation's reasoning and dependence on physical needs and functions. Mekaps' association with PKK had begun in a pure functional context, and it was not the members or sympathisers who first build this semantic association, although it had also embraced and used by them later on. Instead, different actors, mainly political figures and mass media had constructed this semantic association. In addition, the object gained political, ideological, legal, and even criminal 
associations; yet none of them were intended or controlled by the manufacturer or the imagined user. While all the actors involved in in this semantic journey had significant roles, the leading roles of political figures and mass media cannot be overlooked. For both, that are targeting large masses through a direct and simple communication, these associations and metaphoric uses became favourable and functional. But on the other hand, they gave rise to a popular and novel cultural code, a strong identity symbol, that may either be admirable or bete noire. Either labelled as a blessed resistance object or a cursed terrorist shoe, Mekap's story renders a Western dream turning into an evidence of guilt. Yet, the case shows that apart from the biased political history of the near past, the testimonies of objects and the narratives generated upon them may also contribute to enlighten alternative histories.

\section{References}

Cemal, H. (2016). 'Fehman Hüseyin...', published in T24, Retrieved from < http://t24.com.tr/yazarlar/hasancemal/fehman-huseyin,15006>, in 21.07.2016

Edensor, T. (2002) National identity, Popular culture and everyday life, Oxford: Berg Publishers.

Fallan, K. (2010) Design History: Understanding Theory and Method, Oxford: Berg Publishers.

Gottdiener, M. (1995) Postmodern Semiotics: Material Culture and the Forms of Postmodern Life, Oxford: Basil Blackwell Ltd.

Himam, D. (2007) 'Gündelik yaşam nesnesi olarak giysiler: Sümerbank örneği', in 4T Türkiye Tasarım Tarihi Topluluğu Bildiri Kitabı, İzmir: İzmir Ekonomi Üniversitesi.

Karlikli, Ş. (2003). 'Dağa çıkanın rüyası: Mekap spor ayakkabısı', in Milliyet Gazetesi, 13 Aralık 2003.

Lees-Maffei, G. (2009) 'The Production-Consumption-Mediation Paradigm', Journal of Design History. vol. 22, no. 4, pp. 351-376.

Oğhan, Ş. (2013, May 5) 'Mekap'ın dili olsa', in Hürriyet Gazetesi. Retrieved from <http://www.hurriyet.com.tr/pazar/23206064.asp>, in 08.02.2016.

Ozturan, E (2015) A Historical Study on the Changing Meanings of an Artefact: The Biography of Fez in the Context of Material Culture (Unpublished Master's thesis). Istanbul Technical University, Istanbul.

Simmel, G. (1971) 'On Individuality and Social Forms: Selected Writings', Levine, D. N. (ed.), Chicago: University of Chicago Press.

Şen, L. and Gemici, H. (2004, February 26) 'PKK'Iılar sağlam diye Mekap giydi, üreticisi canından bezdi', in Sabah Gazetesi. Retrieved from <http://arsiv.sabah.com.tr/2004/02/26/eko104.html>, in 08.02.2016.

Url-1: Retrieved from <http://www.mekap.com/about.html>, in 08.02.2016.

Url-2: Retrieved from < http://www.radikal.com.tr/turkiye/mekapli-klibe-ceza-1506209/>, in 22.04.2016.

Url-3: Retrieved from <http://www.t24.com.tr/haber/sanik-mekap-ayaga-kalk,58743>, in 08.02.2016.

Url-4: Retrieved from <http://www.kolektifbilincinserzenisleri.blogspot.com.tr/2012/04/mekaplar-suc-deliliolmaya-devam-ediyor.html>, in 08.02.2016.

Url-5: Retrieved from <http://www.haberturk.com/gundem/haber/181396-erdogandan-cok-kritik-uyari>, in 08.02.2016.

Url-6: Retrieved from <http://www.etha.com.tr/haber/2012/05/08/guncel/antepte-kimse-mekap-giymez>, in 08.02.2016.

Url-7: Retrieved from <http://www.hurriyet.com.tr/gundem/22832617.asp>, in 08.02.2016.

Url-8: Retrieved from <https://twitter.com/leylaalp/status/517432669014347776>, in 08.02.2016.

\section{Biographical note}

Emrah Ozturan is holding Bachelor and Master degrees in the product design. He is currently a Ph.D. candidate in the Industrial Product Design Department at Istanbul Technical University, where he also acts as a research assistant since 2012. His research interests are in design history, design culture, material culture and political symbolism. 